\title{
Orientation hydrogeochemical survey in Jebal-e-Barez area, SE Iran
}

\author{
Kaveh Pazand $^{1} \cdot$ Ali Reza Javanshir ${ }^{2}$
}

Received: 24 June 2015/Accepted: 4 August 2015/Published online: 15 August 2015

(C) Springer International Publishing 2015

\begin{abstract}
Geochemical data from 67 spring locations within the $3780 \mathrm{~km}^{2}$, in Jebal-e-Barez area, south eastern of Iran, were analyzed with the purpose of developing a suitable regional geochemical exploration method for $\mathrm{Cu}-$ $\mathrm{Au} \pm$ Mo mineralization in such potential area. Statistical data analyses, graphical methods, and geochemical characteristics of waters and mineral saturation indices were used to identify mineralization potential regions. Hydrogeochemical data of samples suggested that the groundwater is mostly $\mathrm{Ca}+\mathrm{Mg}+\mathrm{HCO}_{3}$ type $(67.16 \%)$. The sulfate-type waters are mainly clustered around the mineralization occurrences. The groundwaters have low concentrations of base metal and $\mathrm{Cu}, \mathrm{Au}, \mathrm{Mo}$ and $\mathrm{SO}_{4}$ can be used as direct indicators of $\mathrm{Cu}$ mineralization in study area. $\mathrm{Ni}$ is an indicator of $\mathrm{Cu}$ mineralization and travertine springs distribution impress the hydrogeochemical evaluation. On this basis, it is concluded hydrogeochemical exploration can be used as an effective regional exploration method.
\end{abstract}

Keywords Hydrogeochemical · Mineralization · Exploration · Jebal-e-Barez

Kaveh Pazand

kaveh.pazand@gmail.com

1 Young Researchers and Elite Club, Science and Research Branch, Islamic Azad University, Tehran, Iran

2 Department of Geology, Tarbiat Modares University, Tehran, Iran

\section{Introduction}

The chemical characteristics of groundwaters in the absence of human perturbations are the result of several geochemical processes that are closely linked to the local natural environment. Chemical reactions such as weathering, dissolution, precipitation, ion exchange and various biological processes commonly take place below the surface on both vertical and horizontal dimensions on different scales (Pazand et al. 2012; Demdoum et al. 2014). Hydrogeochemical study is a useful tool to identify these processes that are responsible for groundwater chemistry (Jeevanandam et al. 2007). There are many examples of the use of Hydrogeochemistry in mineral exploration and environmental studies in the world (Miller et al. 1982; Hartikainen 1992; Giammanco et al. 2007; Verplanck et al. 2008; Halim et al. 2009; Hame et al. 2014). Appreciation of basic principles in aqueous geochemistry provides a means to understanding element mobility's and interpreting dispersion patterns, with applications in both the mineral exploration and environmental disciplines. Applied hydrogeochemistry in mineral exploration peaked in the 1970s, but a new episode in hydrogeochemical mineral exploration has been opened, and investigation of robust element anomalies and dispersion patterns, at concentration levels unattainable a decade ago, can now proceed on a cost-effective basis (Taufen 1997). Previous hydrogeochemical studies of spring waters have been largely designed to predict environmental impacts of mines, rather than for exploration purposes (Caron et al. 2008) while hydrogeochemical study can quickly identify mineralized zones in a large area given a limited budget and field season. Because many surfaces and near-surface mineral deposits have been discovered, the challenge for mineral exploration is to find new, more deeply buried deposits, 


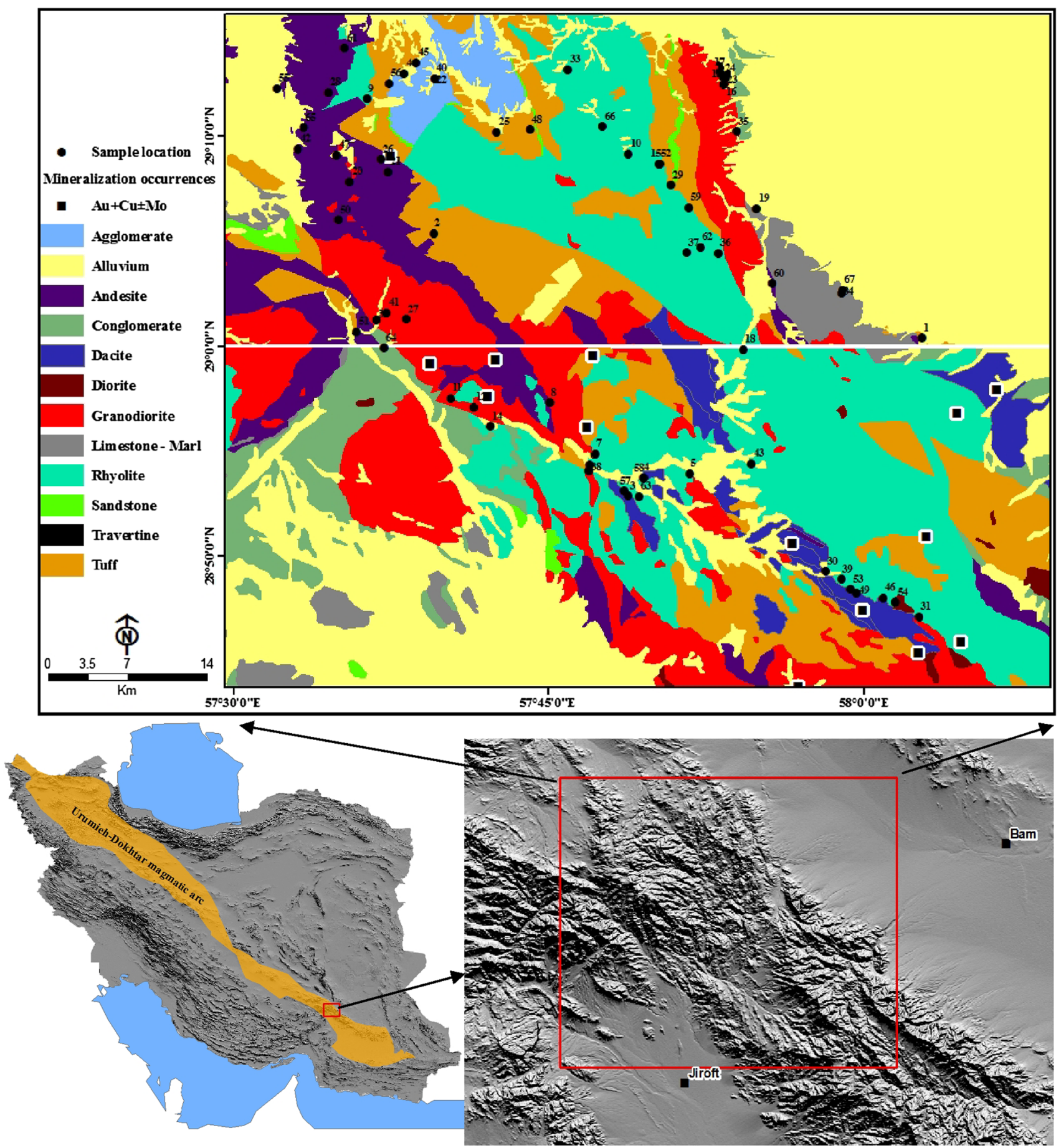

Fig. 1 Simplified geological map of the Jebal-e-Barez, mineralization occurrences and spring sample location (modified from Aghanabati et al. 1992; Aghanabati and Eftekhar Nezhad 1993; Babakhani and Alavai Tehrani 2002)

particularly in areas where thick cover exists (Cameron et al. 2004). The main purpose of the study was to determine the water-rock interactions in the study area and developing a suitable regional geochemical exploration method for such areas. Groundwater is a geochemical sampling medium that moves through the subsurface, is easily collected and can be analyzed with great accuracy and sensitivity, especially in areas such as Jebal-e-Barez where groundwater returns to the surface by exist springs. With the absence of wells in the present large study area, springs are relied on as natural discharge of groundwater. Previous work in the southern Canadian Cordillera has 


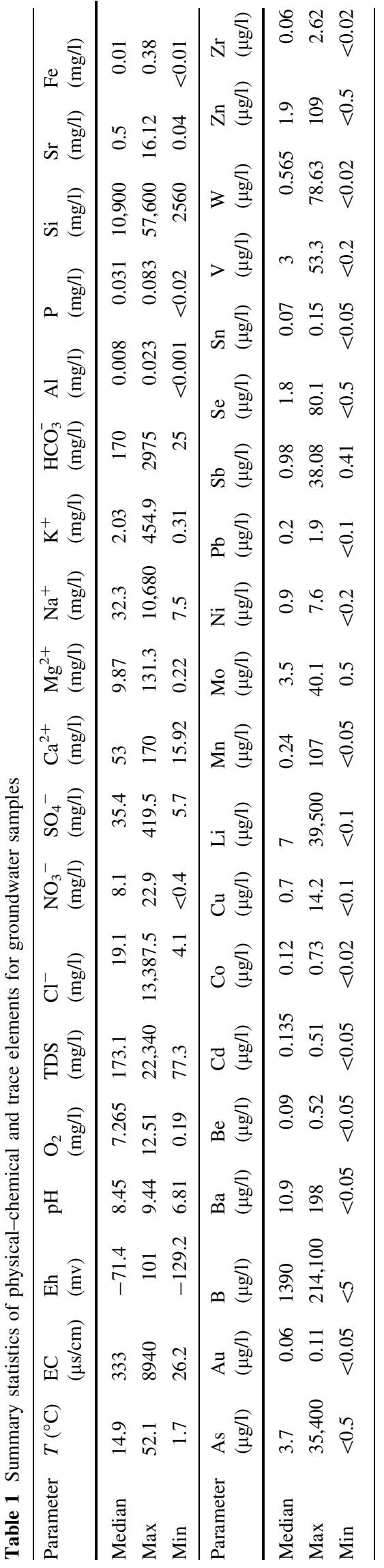

shown that the deep circulation of meteoric water, and discharge of groundwater as discrete springs, is often controlled by geologic features similar to those that focused on movement and deposition of hydrothermal ore deposits, making it likely that modern day spring circulation systems may intersect hidden ore deposits (Caron et al. 2008).This paper was undertaken to evaluate the use of hydrogeochemical exploration for $\mathrm{Cu}, \mathrm{Au}, \mathrm{Mo}$ and other mineral deposits, and the distribution of indicator elements in spring waters and geochemical characteristics of waters has been studied with discusses their geochemical relationship.

\section{Geological settings}

The study area, covering about $3780 \mathrm{~km}^{2}$, is located in the province of Kerman, south east of Iran, between of the Bam and Jiroft city and is a part of the Urumieh-Dokhtar magmatic zone (Fig. 1). The area has a hot arid climate, with mean maximum summer temperatures (July) of about $45^{\circ} \mathrm{C}$ and minimum winter temperatures (January) of $15{ }^{\circ} \mathrm{C}$. The climate of the study area is considered to be arid, the annual precipitation being approximately $100 \mathrm{~mm}$. The Urumieh-Dokhtar volcanic belt trending NW-SE is located in the Tethyan Copper Belt of Iran (Beiranvand Pour and Hashim 2012). It is the product of Tethys oceanic plate subduction under the Iranian microplate followed by continent-to-continent collision of the Arabian and Eurasian plates (Alavi 1994; Regard et al. 2004), which is classified as an Andean volcanic arc (Alavi 1980; Berberian et al. 1982). In Iran, many of the known and mined porphyry copper deposits are concentrated in this belt, and are particularly widespread in the southeastern belt segment (Shafiei et al. 2009; Dargahi et al. 2010). Figure 1 shows a simplified geology map of the study area. In the Urumieh-Dokhtar belt, mountains include a volcanic succession of Eocene calc-alkaline basaltic andesites and Oligocene shoshonitic rocks intruded by Neogene quartz diorites, quartz monzonites and granodiorites, which contain vein-type and porphyry copper mineralization. The most of volcanism occurred from Eocene to Miocene time in this belt (Hubner 1969). The Jebal-e-Barez mountain range is a large batholith as a lens shaped and morphological point of view by deep valleys and streams are interrupted. Due to the Miocene magmatic activity, multistage batholith has intruded into Eocene volcanic rocks (Rasoli and Ghorbani 2011). The outcrop rocks are formed of granodiorite, rhyolite, tuff and andesite that surrounded by a series of sedimentary rocks as sandstone, conglomerate, limestone and quaternary alluvium. In parts of the region, particularly in central and southeastern, diorite units are observed. The travertines related to volcanic 

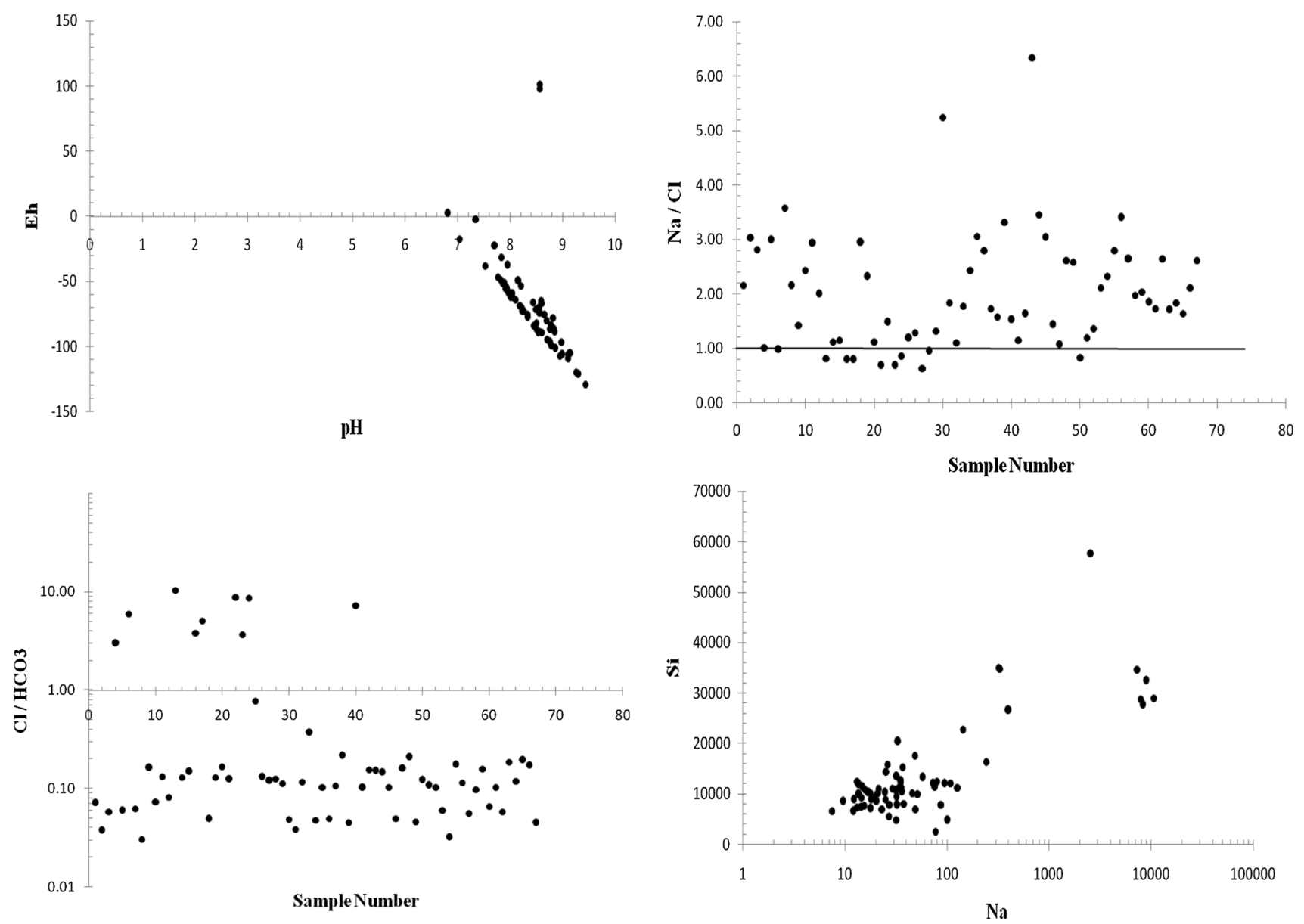

Fig. 2 Correlation of $\mathrm{Eh}$ vs. $\mathrm{pH}, \mathrm{Si}$ vs. $\mathrm{Na}$ and $\mathrm{Na} / \mathrm{Cl}$ ratio and $\mathrm{Cl} / \mathrm{HCO}_{3}$ ratio index of water samples in the study area

setting in the northern part of the study area. A number of small mineralization occurrences such as $\mathrm{Au}, \mathrm{Cu}$ and $\mathrm{Mo}$ in the study area are observed (Fig. 1).

\section{Groundwater sampling and analysis}

Groundwater samples were collected from 67 springs within the study area in December, 2011. They were stored in $100 \mathrm{ml}$ polyethylene bottles. On-site measurements of $\mathrm{pH}$, electrical conductivity, temperature, dissolved oxygen concentration and Eh were determined using a multiparameter portable meter (HACH, Germany). At each site, the $\mathrm{pH}$ electrode was calibrated using two buffers (Merck, Germany) that bracketed the measured $\mathrm{pH}$ and that were thermally equilibrated with the water sample. Titration techniques were used to analyze total alkalinity $\left(\mathrm{HCO}_{3}{ }^{-}+\right.$minor $\left.\mathrm{CO}_{3}{ }^{2-}\right)$ and ion chromatography for anions $\left(\mathrm{Cl}^{-}, \mathrm{NO}_{3}{ }^{-}, \mathrm{SO}_{4}{ }^{2-}\right)$. Cations, base metal and other major and trace elements were measured by inductively coupled plasma mass spectrometry (ICP-MS) in the filtered and acidified water samples within 2 weeks after sampling.
The analytical precision for total measurements of the cations and anions was checked by calculating ionic balance errors and most of them were within $\pm 5 \%$.

\section{Results and discussion}

\section{Main hydrogeochemical features}

A statistical summary of physical-chemical parameters and trace elements is presented in Table 1 .

Groundwater $\mathrm{pH}$ is predominantly near neutral to alkaline (6.81-9.44). Electrical conductivity (EC) of groundwater widely varies from 26.2 to $8940 \mu \mathrm{S} / \mathrm{cm}$. The large variation in EC is mainly attributed to geochemical processes prevailing in this region. The Eh can be used with other redox indicators to ascertain, in a qualitative sense, the relative redox conditions of an aquifer (Smedley and Edmunds 2002). The values of the redox potential are in the range -129.2 to $101 \mathrm{mV}$ and demonstrate except two samples (samples 22 and 40) the reducing aquifers are presented in the study areas. The relationship 


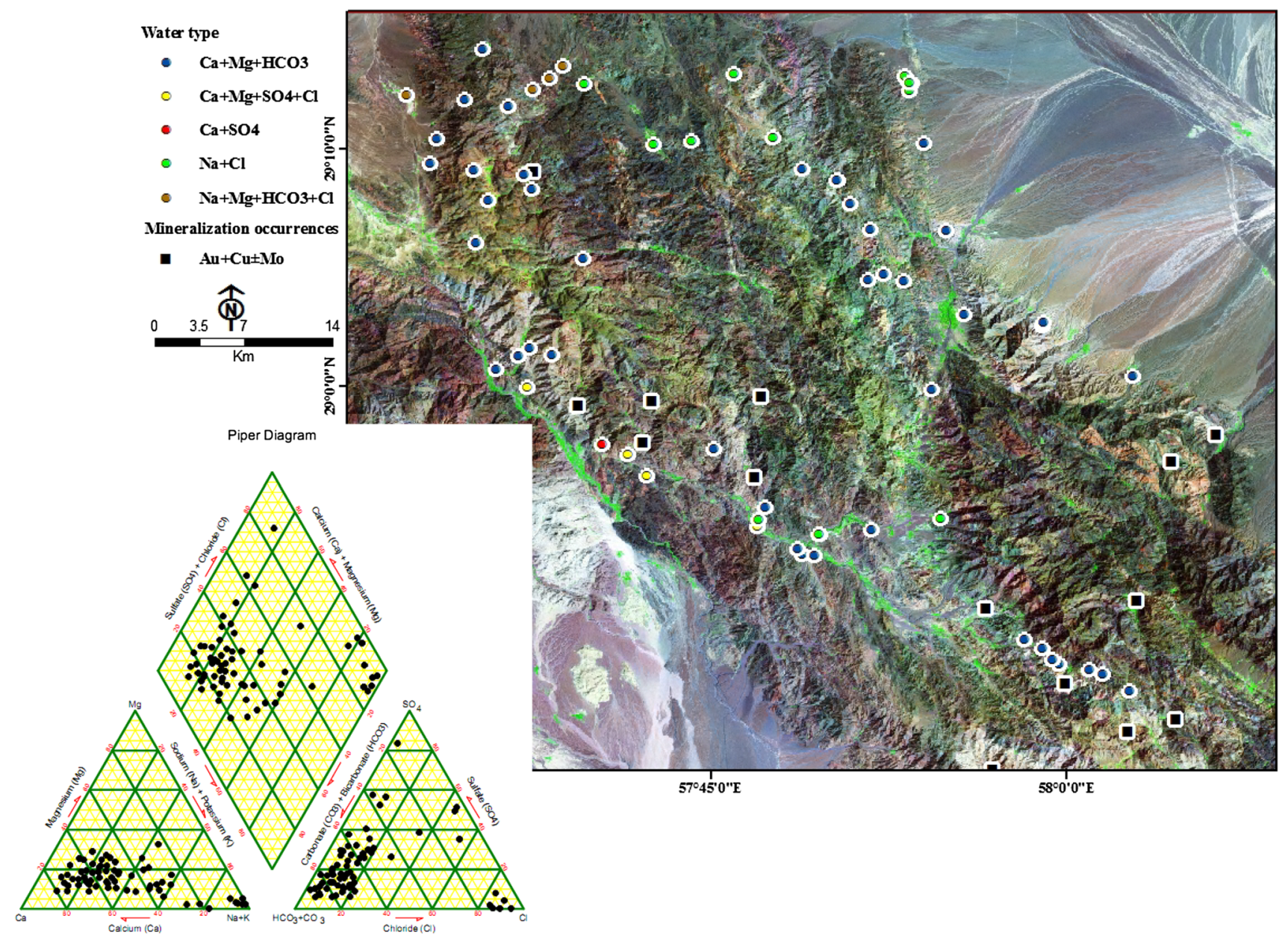

Fig. 3 Distribution of water types in water samples and piper diagram for study area

between $\mathrm{Eh}$ and $\mathrm{pH}$ shows that $\mathrm{Eh}$ decreases with increasing $\mathrm{pH}$ (Fig. 2); this relationship probably indicates the progressive reduction of $\mathrm{Fe}^{2+}$ with deeper circulation associated with $\mathrm{pH}$ increase (Pazand 2014). Total dissolved solid (TDS) is an important parameter that can be used to observe the influence of major components in groundwater quality, and as a function of mineralization characteristics (Paznand and Javanshir 2014), the TDS of the groundwater samples ranges from 77.3 to $22340 \mathrm{mg} / \mathrm{l}$, with a median value of $173.1 \mathrm{mg} / \mathrm{l}$. The concentration of major cations, e.g., $\mathrm{Ca}^{2+}(15.92-170 \mathrm{mg} / \mathrm{l}), \mathrm{Mg}^{2+}(0.22-$ $131.3 \mathrm{mg} / \mathrm{l}), \mathrm{Na}^{+}(7.5-10,680 \mathrm{mg} / \mathrm{l})$ and $\mathrm{K}^{+}(0.31-$ $454.9 \mathrm{mg} / \mathrm{l})$ exhibits high variation in water samples. The major anions $\mathrm{HCO}^{3-}(25-2975 \mathrm{mg} / \mathrm{l}), \mathrm{SO}_{4}{ }^{2-}$ (5.7$419.50 \mathrm{mg} / \mathrm{l})$ and $\mathrm{Cl}^{-}(4.1-13387.5 \mathrm{mg} / \mathrm{l})$ also have great variability in the area. In most of the samples $(85 \%)$ having $\mathrm{Na}^{+} / \mathrm{Cl}^{-}$ratio greater than 1 (Fig. 2) indicated that an ion exchange process is prevalent in the study area and might have come from silicate weathering most likely by feldspar weathering via a reaction such as (Paznand and Javanshir 2013):

$$
\begin{aligned}
& 2 \mathrm{NaAlSi}_{3} \mathrm{O}_{4}(\text { albite })+9 \mathrm{H}_{2} \mathrm{O}+2 \mathrm{H}_{2} \mathrm{CO}_{3} \\
& =\mathrm{Al}_{2} \mathrm{Si}_{2} \mathrm{O}_{5}(\mathrm{OH})_{4}(\text { kaolinite })+2 \mathrm{Na}^{+}+2 \mathrm{HCO}_{3}^{-} \\
& \quad+4 \mathrm{H}_{4} \mathrm{SiO}_{4} .
\end{aligned}
$$

In other samples, $\mathrm{Na}^{+} / \mathrm{Cl}^{-}$ratio is $<1$ often in travertine parts of the area (Fig. 1), indicating that the process of ion exchange is the predominant process for reduction of $\mathrm{Na}^{+}$ in these groundwaters. The molar ratio of $\mathrm{Cl}^{-}$and bicarbonate $\left(\mathrm{HCO}_{3}{ }^{-}\right)$is used to distinguish between freshwater and saline water. Seawater has very high $\mathrm{Cl}^{-} / \mathrm{HCO}_{3}{ }^{-}$ molar ratio (>200), while fresh water usually shows $\mathrm{Cl}^{-}$/ $\mathrm{HCO}_{3}{ }^{-}<1$ and molar ratio of $\mathrm{Cl}^{-} / \mathrm{HCO}_{3}{ }^{-}>1$ indicates mixing of seawater with fresh water (Raghunath 1987). Plots of molar $\mathrm{Cl}^{-} / \mathrm{HCO}_{3}{ }^{-}$(Fig. 2) show that major the samples $(86.5 \%)$ have $\mathrm{Cl}^{-} / \mathrm{HCO}_{3}{ }^{-}<1$ indicating freshwater, and others show mixing of seawater with fresh water. 


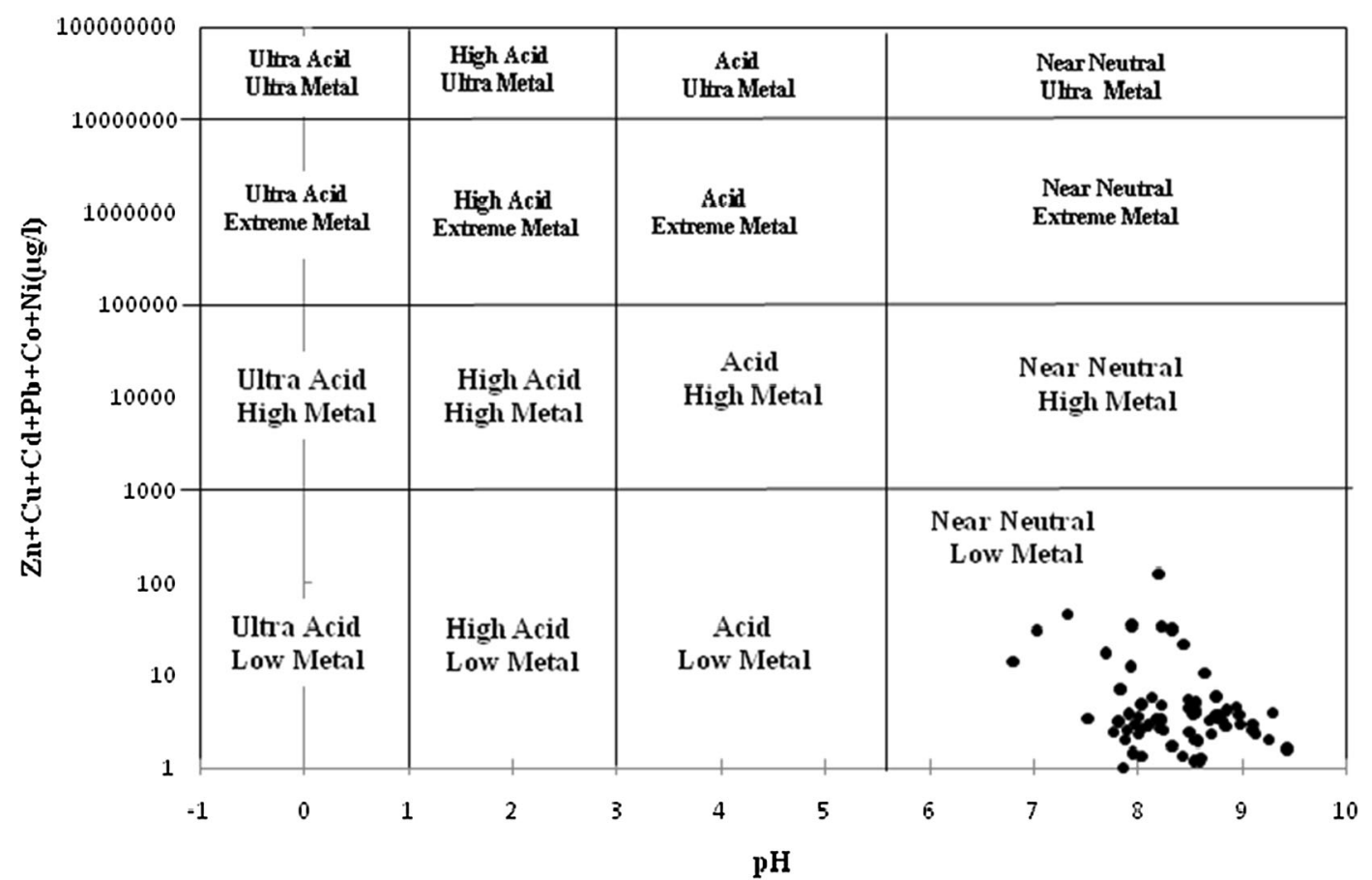

Fig. 4 Ficklin diagram showing variations in aqueous base metal concentrations as a function of $\mathrm{pH}$ for the study area

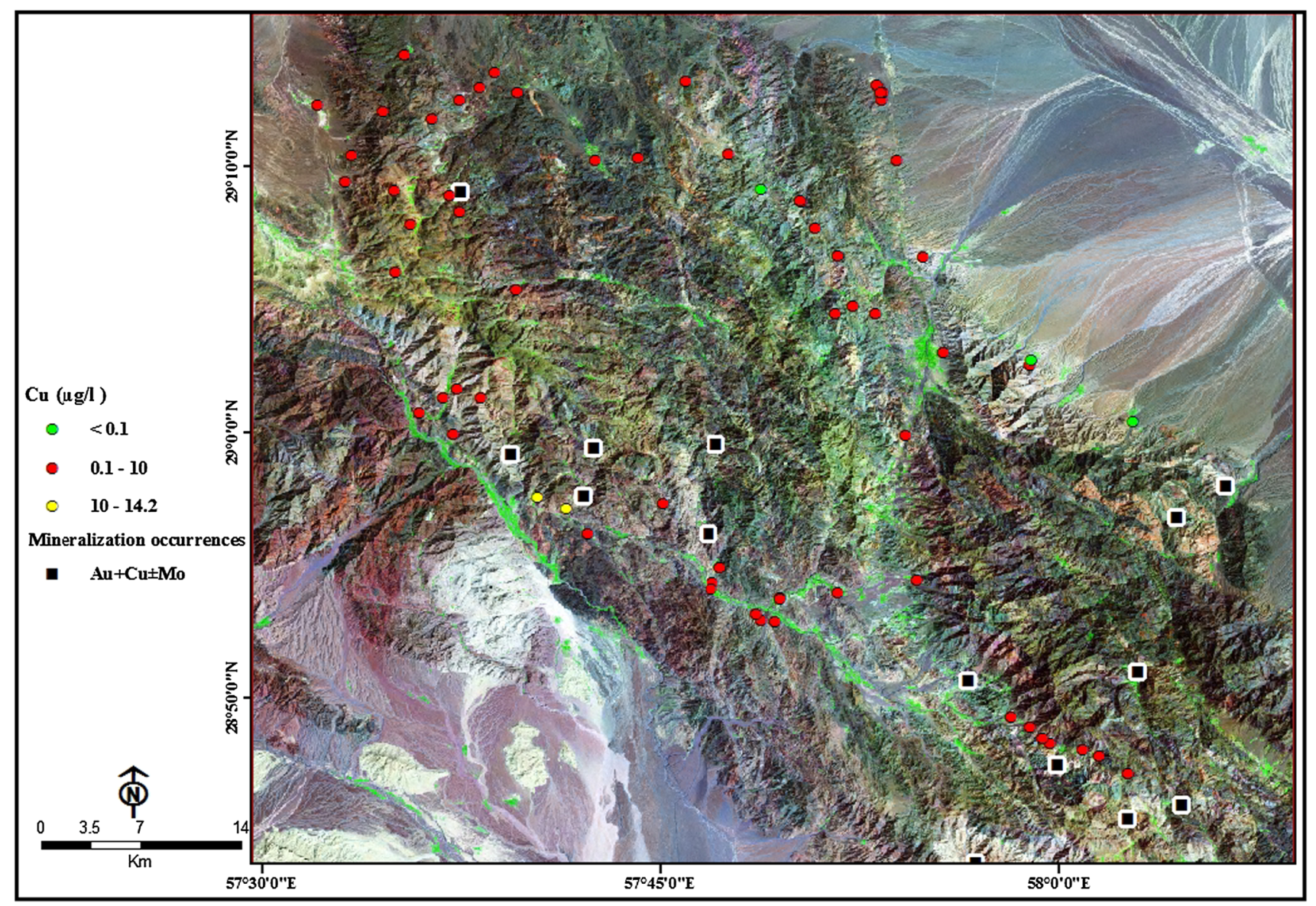

Fig. 5 Spatial distribution of $\mathrm{Cu}$ in study area 


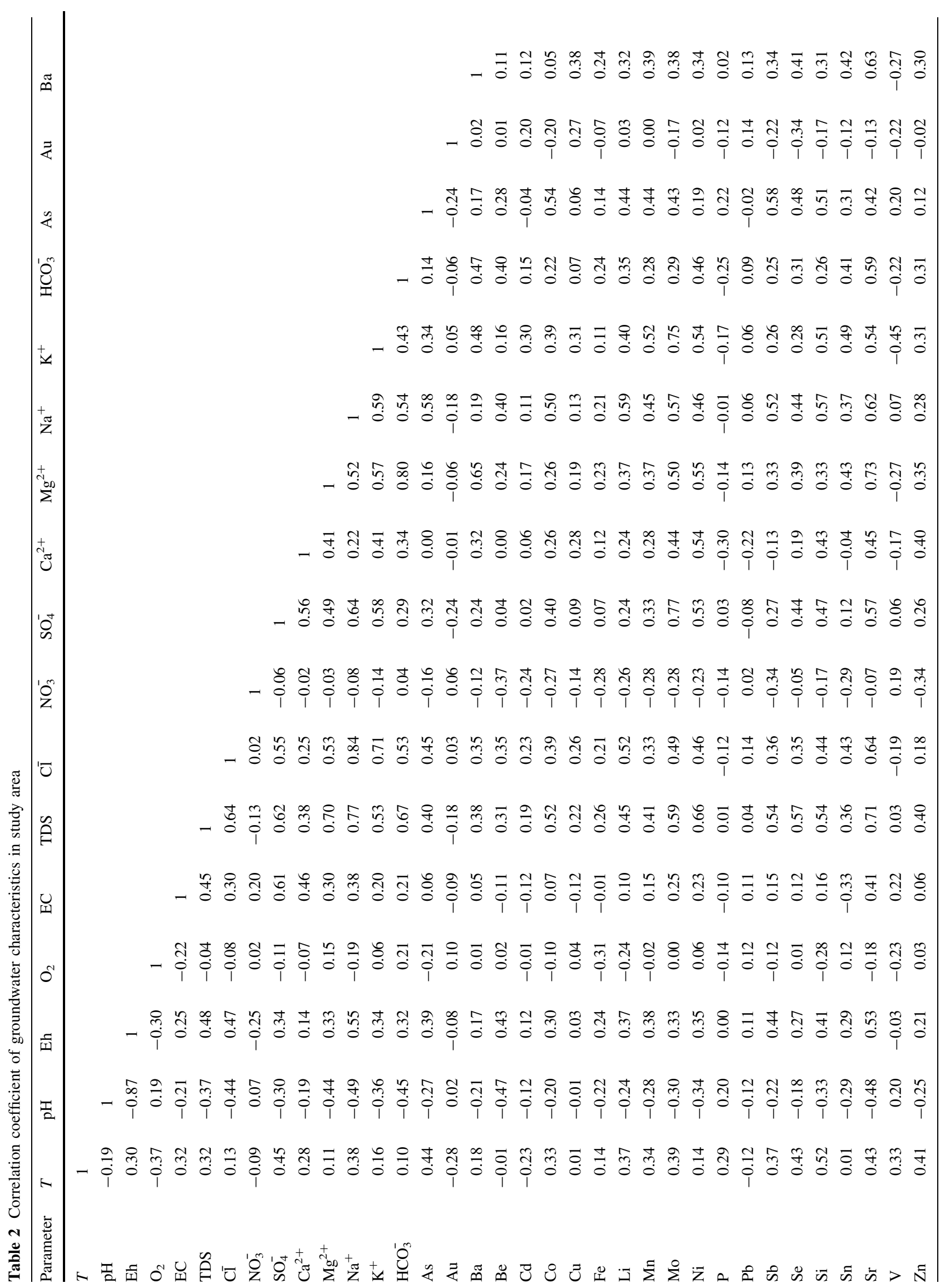




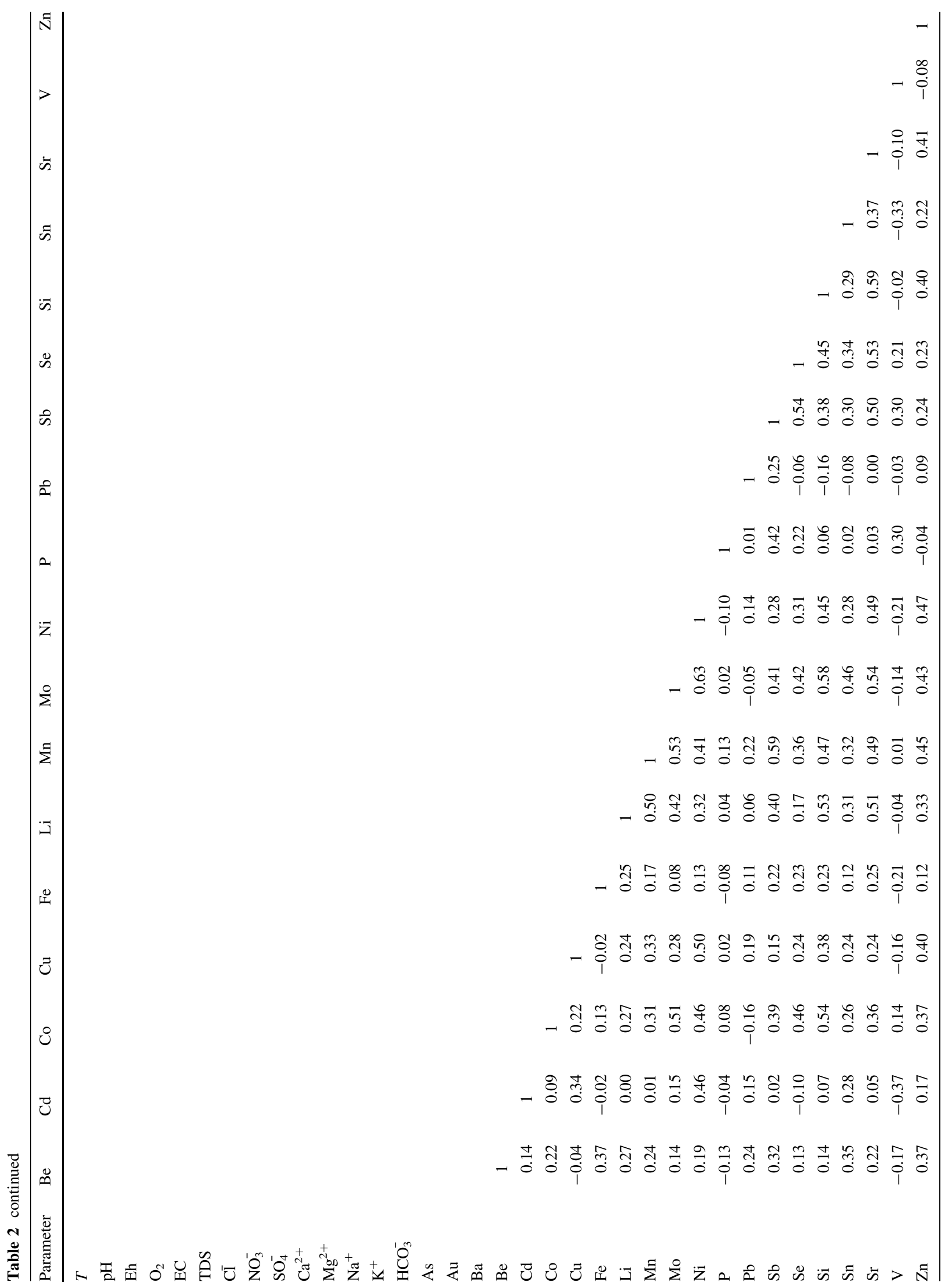



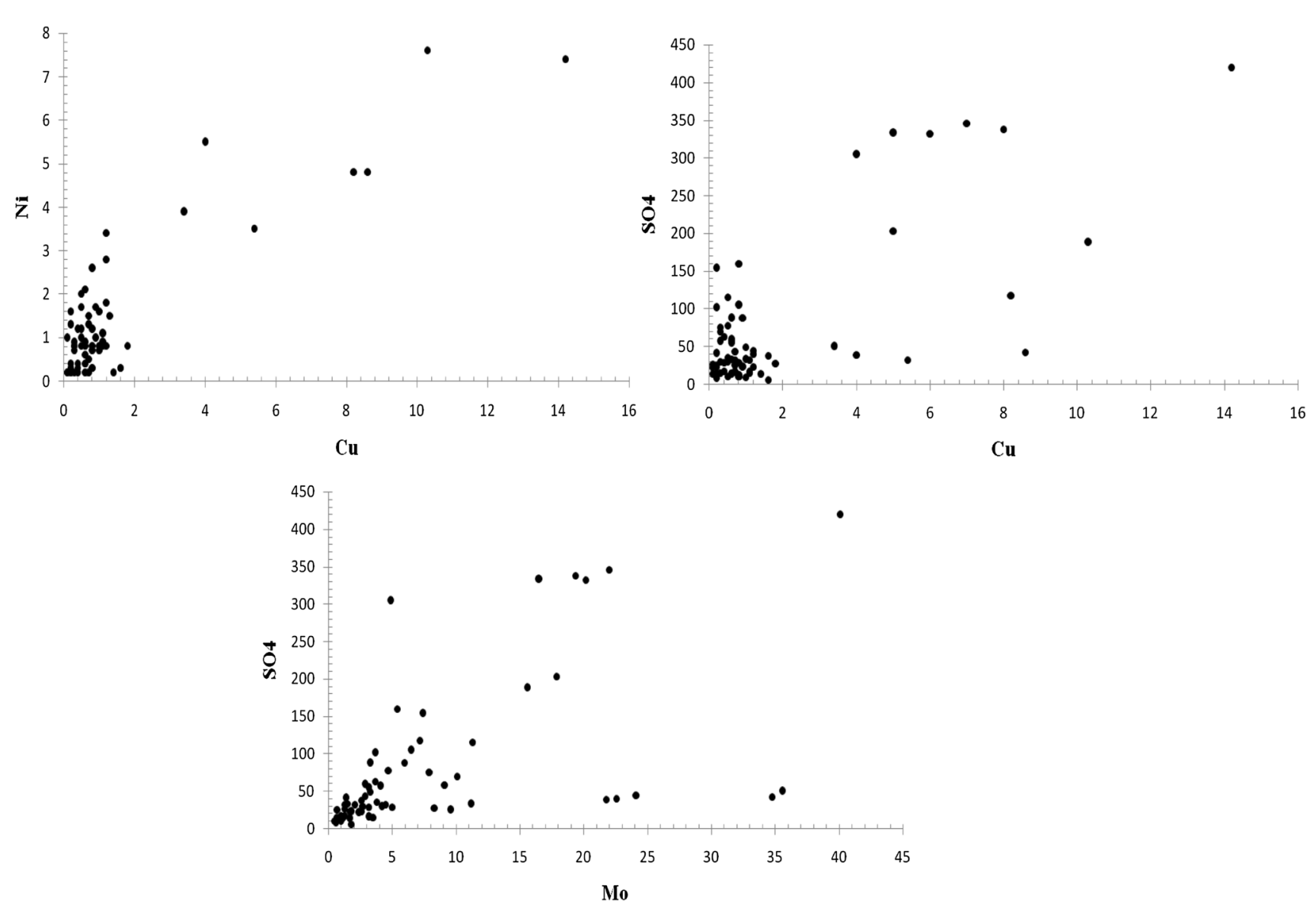

Fig. 6 Correlation of $\mathrm{Ni}$ vs. $\mathrm{Cu}, \mathrm{Cu}$ vs. $\mathrm{SO}_{4}{ }^{2-}$ and $\mathrm{Mo}$ vs. $\mathrm{SO}_{4}{ }^{2-}$ in the study area

Based on the dominant cations and anions, five water types were found for the water samples (Fig. 3): $\mathrm{Ca}+\mathrm{Mg}+\mathrm{HCO}_{3}, \mathrm{Na}+\mathrm{Cl}, \mathrm{Na}+\mathrm{Mg}+\mathrm{HCO}_{3}+\mathrm{Cl}$, $\mathrm{Ca}+\mathrm{Mg}+\mathrm{SO}_{4}+\mathrm{Cl}$ and $\mathrm{Ca}+\mathrm{SO}_{4}$ that represent $67.16,19.4,5.97,5.97$ and $1.5 \%$ of the total number of water samples, respectively. Bicarbonate-type waters are usually derived from normal weathering reactions involving rock minerals and water containing dissolved $\mathrm{CO}_{2}$ (Miller et al. 1982). Sulfate-type waters often are derived from the dissolution of sulfide minerals, such as pyrite and $\mathrm{Na}-\mathrm{Cl}$ type particularly in areas underlain by sedimentary rocks. Distributions of water types are shown in Fig. 3. The sulfate-type waters are mainly clustered around the mineralization occurrences that are a good indicator of sulfide minerals, particularly pyrite.

\section{Minor and trace element hydrogeochemistry}

Concentrations of minor elements in the studied waters show large variation depending on the mineral solubility, $\mathrm{pH}, \mathrm{Eh}$ and salinity of the solution. The Ficklin plot is a scatter diagram in which the sum of the base metals is plotted against $\mathrm{pH}$ and is an easy and effective mean of classifying water samples based on differences in the sum of base metal concentrations (Manjo et al. 2012). Differences in the sum of $\mathrm{Zn}, \mathrm{Cu}, \mathrm{Cd}, \mathrm{Pb}, \mathrm{Co}$ and $\mathrm{Ni}$ concentrations for different samples allow in differentiating various geological controls based on their resultant water chemistry. The Ficklin plot classified all water samples as near-neutral low-metal waters (Fig. 4).

Concentration of $\mathrm{Cu}$ in groundwater is observed between $<0.1$ and $14.2 \mu \mathrm{g} / 1$ with mean value $0.7 \mu \mathrm{g} / \mathrm{l}$ in the study area. Bioavailability of $\mathrm{Cu}$ in the water influenced by the size of the initial $\mathrm{Cu}$ amendment, timedependent changes in speciation, and soil humidity and the retention of $\mathrm{Cu}$ are enhanced under stable humid conditions (Petersen et al. 2004). The samples with high amount of copper (samples 11 and 12 with 14.2 and $\mu \mathrm{g} / \mathrm{l}$, respectively) are associated with mineralization occurrences (Fig. 5) and the sulfate-type waters (Fig. 3). Strong correlation between copper and other elements cannot be seen (Table 2).

The concentrations of $\mathrm{Ni}$ in these spring waters are much higher than other areas where $\mathrm{Ni}$ concentrations are quite low. The $\mathrm{Cu}$ and $\mathrm{Ni}$ concentrations were significantly correlated (Fig. 6). Therefore, Ni can be considered as an indicator of $\mathrm{Cu}$ mineralization in the study area. The 


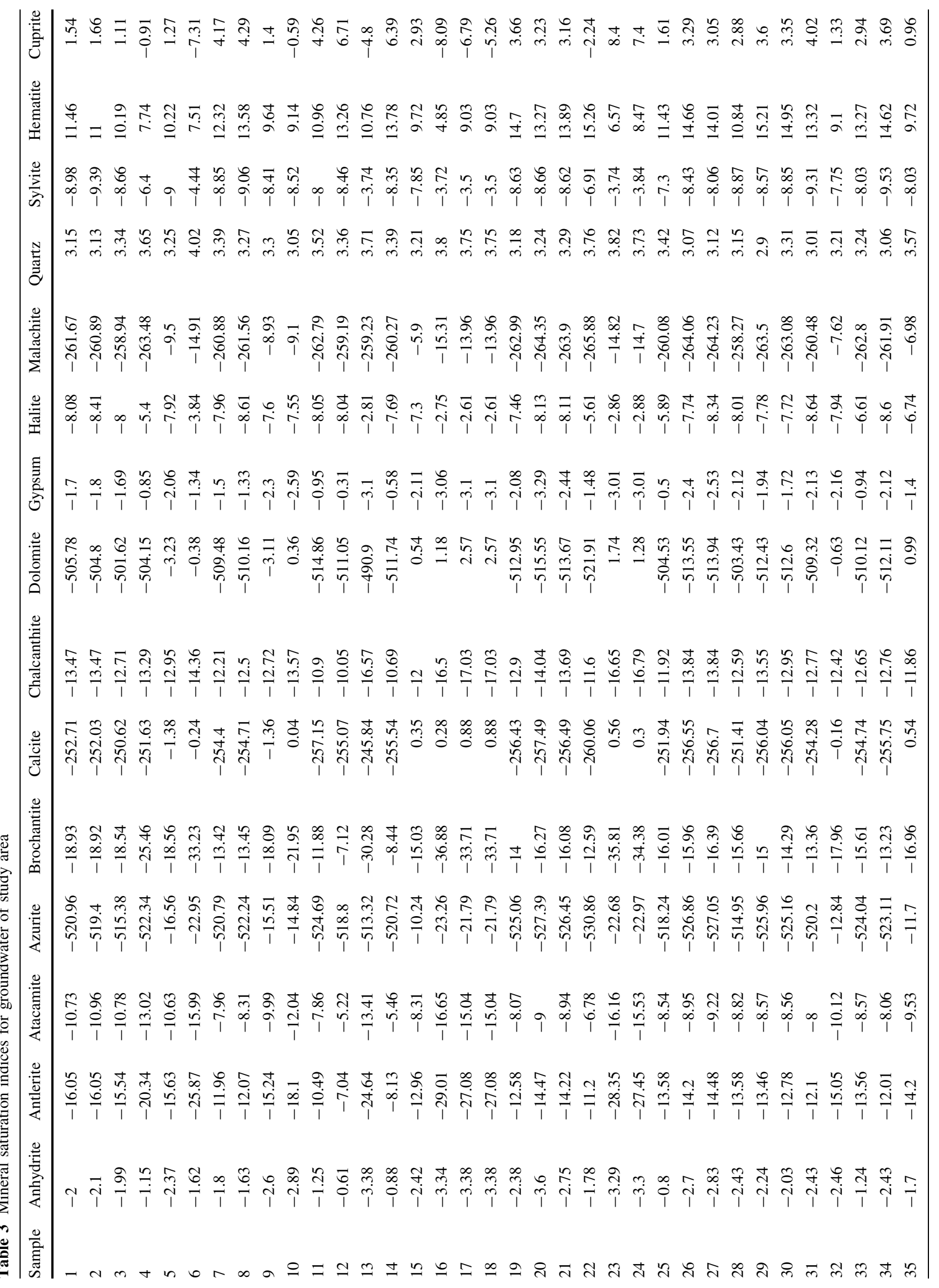




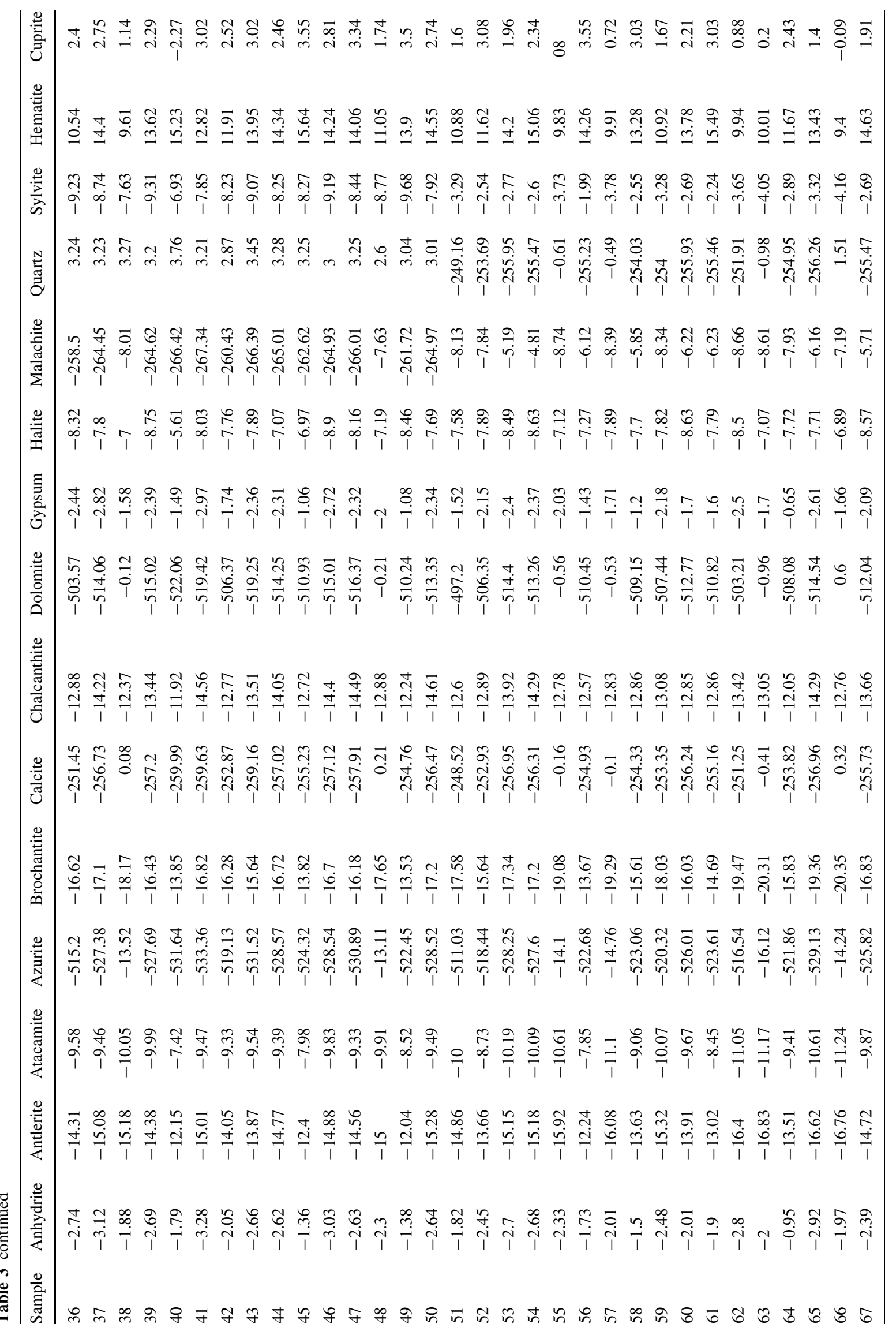




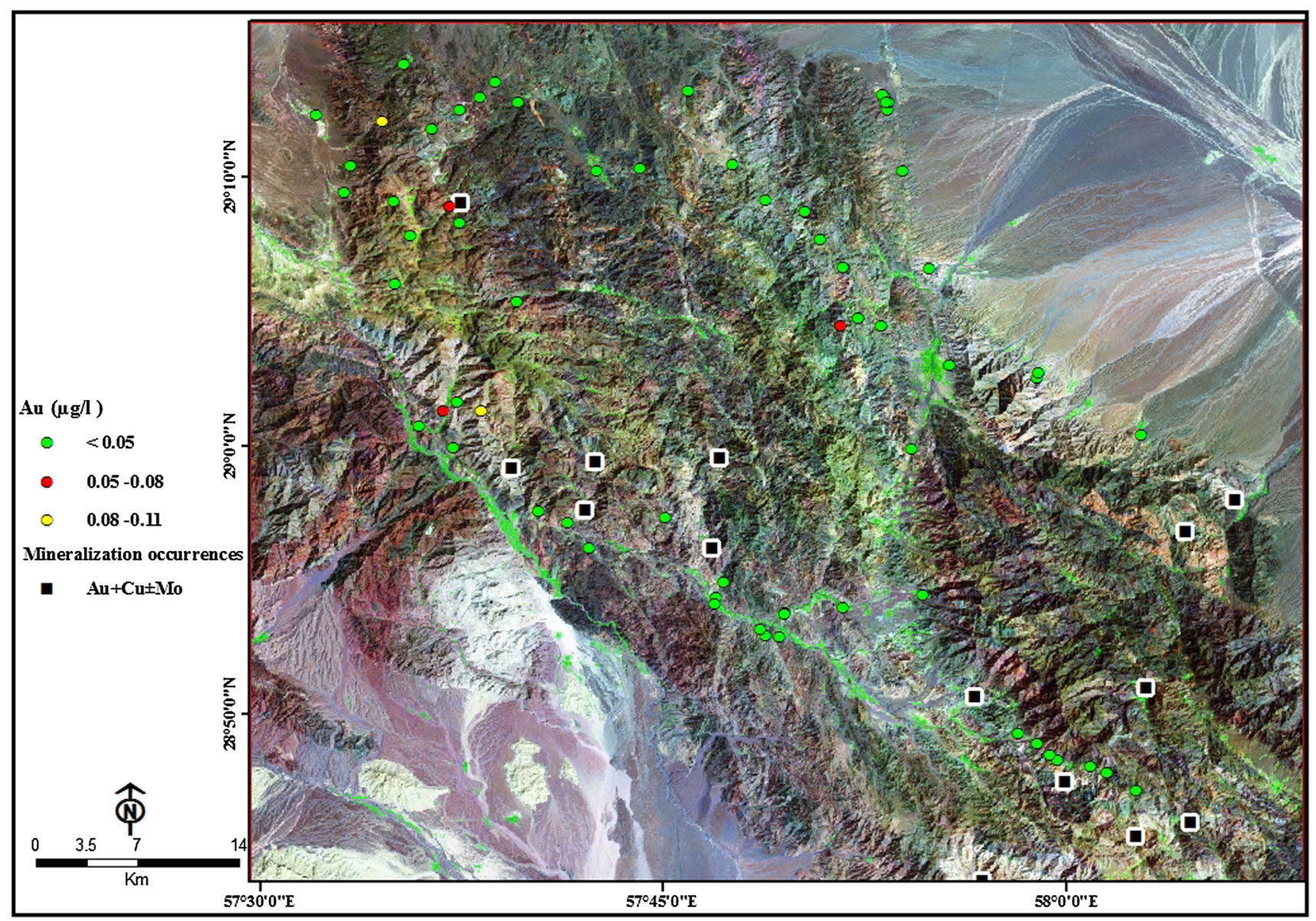

Fig. 7 Spatial distribution of $\mathrm{Au}$ in study area

oxidation of sulfide minerals (e.g., chalcopyrite, molybdenite) will result in increased concentrations of sulfate, copper and molybdenum (and other trace elements) in solution in groundwater (Fig. 6).

The PHREEQC programs are used to calculate mineral saturation indices for minerals in a groundwater to determine those samples that are most conducive to the formation and/or preservation of an ore deposit (Table 3). Water has a thermodynamic tendency to precipitate phases with calculated saturation indices greater than 0 , and a thermodynamic tendency to dissolve phases with calculated saturation indices less than 0. Other factors, such as kinetics, or the presence or absence of the mineral in contact with the water will also influence whether a mineral dissolves or precipitates (Plumlee et al. 1999). Hematite is precipitating in all the samples, which is a limiting factor for $\mathrm{Fe}$ in groundwater. Precipitation of oxide minerals such as cuprite may limit concentrations of $\mathrm{Cu}$ in the water.

The inverse model indicates that in all locations, primary mineral phases including sylvite, anhydrite and different copper minerals (except cuprite) were set to dissolve until they reached saturation. Dolomite and calcite in most samples set to dissolve and, in travertine area set to precipitate. Quartz was set to precipitate in most samples once they reached saturation.

Gold concentrations are variable, ranging from $<0.05$ to $0.11 \mu \mathrm{g} / \mathrm{l}$ (Fig. 7). Dissolved Au is anomalous, with concentrations greater than $50 \mathrm{ng} / \mathrm{l}(0.05 \mu \mathrm{g} / \mathrm{l})$ suggests that $\mathrm{Au}$ mineralization (though not necessarily economic) occurs throughout the area. Highest dissolved Au concentrations occur in the sample number 26 , and particularly within the sites $27,14,25$ and 31 . Some of this sample is concordant with mineralization occurrences (Fig. 7). All of these sample anomalies are $\mathrm{Ca}+\mathrm{Mg}+\mathrm{HCO}_{3}$ type (Figs. 3, 7).

Molybdenum concentrations range from 0.5 to $40.1 \mu \mathrm{g} /$ 1. The values are low, but the highest values occur over or near the mineralization occurrences especially in the western area. Molybdenum is associated with the porphyry copper deposits, but the amount of molybdenum-bearing minerals is probably low (Miller et al. 1982). 


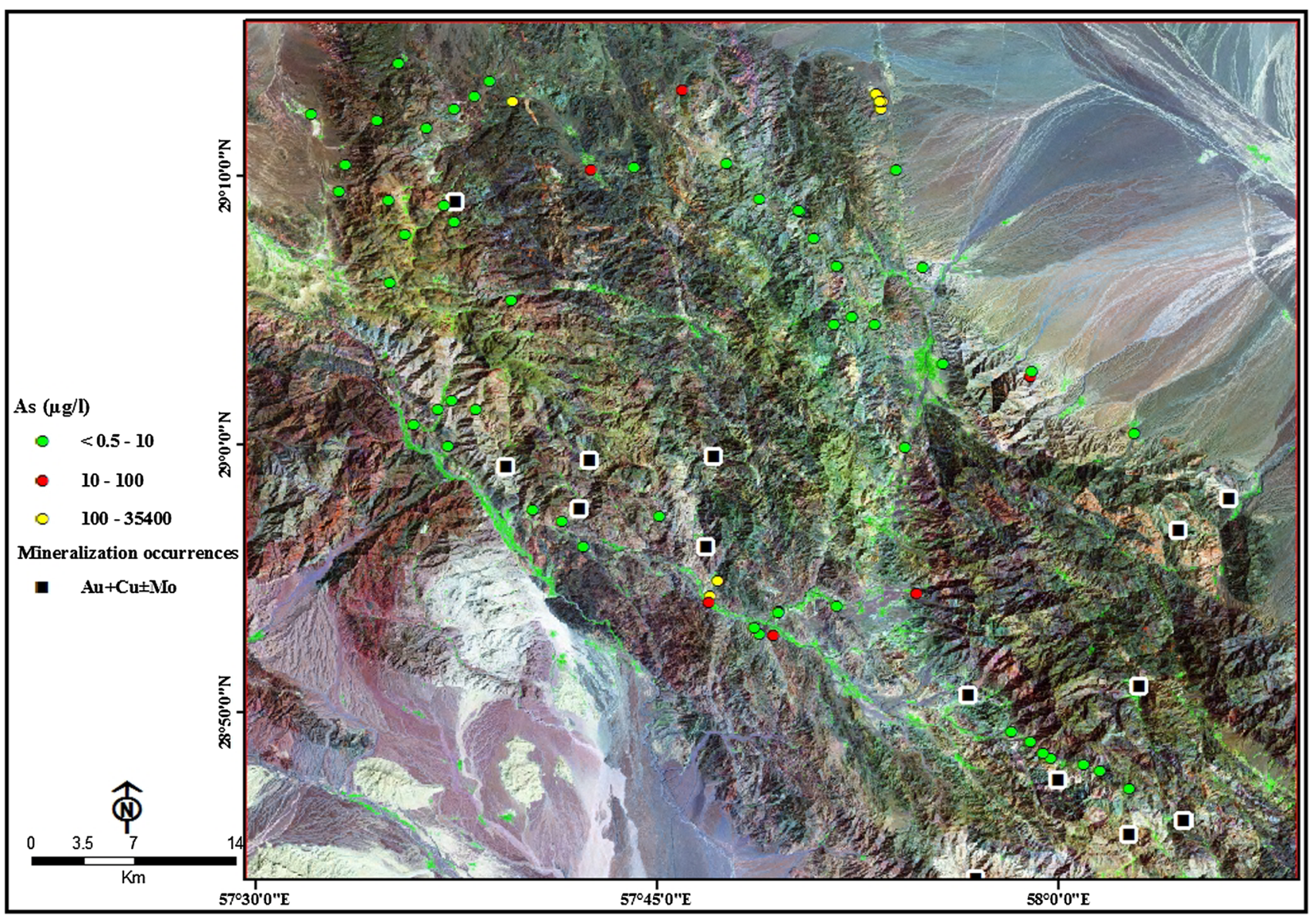

Fig. 8 Spatial distribution of As in study area

Concentrations of dissolved As in the Jebal-e-Barez area range from below detection limit $(<0.5 \mu \mathrm{g} / \mathrm{l})$ to as very high as $35,400 \mu \mathrm{g} / \mathrm{l}$. Similar to Se and $\mathrm{Zn}$, high As concentrations display significant correlation with mineralization and travertine sites (Fig. 8). Travertine springs water (numbers 13, 16, 17, 23 and 24) displays high arsenic content $(25,650-31,650 \mu \mathrm{g} / \mathrm{l})$ as well as high concentration of $\mathrm{Se}, \mathrm{B}, \mathrm{Ba}, \mathrm{Li}, \mathrm{Zn}, \mathrm{Sr}$ and $\mathrm{Sb}$ and reflects the alkaline volcanic nature in the study area.

\section{Conclusions}

The regional sampling of spring discharge and analyses of trace element data can provide a rapid and relatively low-cost reconnaissance exploration tool. The following conclusions can be drawn from the results of the hydrogeochemical investigation of the Jebal-e-Barez area.

1. The groundwater in the study area is mainly characterized by the $\mathrm{Ca}+\mathrm{Mg}+\mathrm{HCO}_{3}$ hydrochemical facies, although other types of water were observed.

2. The silicate weathering is the main process of ion exchange in the study area.
3. The sulfate-type waters are mainly clustered around the mineralization occurrences.

4. The base metal concentrations in groundwater are low.

5. The $\mathrm{Ni}$ can be considered as an indicator of $\mathrm{Cu}$ mineralization in the study area.

6. The $\mathrm{Mo}$ and $\mathrm{SO}_{4}$ can be used as direct indicators of $\mathrm{Cu}$ mineralization in the same area.

7. Precipitation of oxide minerals such as cuprite and hematite may limit concentrations of $\mathrm{Cu}$ and $\mathrm{Fe}$ in the waters.

8. The Au concentrations in solution can be used to mineralization zone reconnaissance.

9. The main source of As in groundwater is dissolution of arsenic-containing minerals and travertine springs.

10. The travertine springs distribution impress the hydrogeochemical study.

11. Hydrogeochemical surveying can be used as an effective regional exploration method for metallic ore provinces.

12. The information provided in this study would be useful for current and future groundwater management in the region. 


\section{References}

Aghanabati A, Eftekhar Nezhad J (1993) Geology map of Bam 1:250000 sheets. Geol Surv Iran

Aghanabati A, Eftekhar Nezhad J, Samimi Namin M, Arshadi S (1992) Geology map of Jahan Abad 1:250000 sheets. Geol Surv Iran

Alavi M (1980) Tectonostratigraphic evolution of the Zagros-sides of Iran. Geology 8:144-149

Alavi M (1994) Tectonic of the Zagros orogenic belt of Iran: new data and interpretations. Tectonophysics 229:211-238

Babakhani AR, Alavi Tehrani V (2002) Geology map of Sabzevaran 1:250000 sheets. Geol Surv Iran

Beiranvand Pour A, Hashim M (2012) Identifying areas of high economic-potential copper mineralization using ASTER data in the Urumieh-Dokhtar volcanic belt, Iran. Adv Space Res 49:753-769

Berberian F, Muir ID, Pankhurst RJ, Berberian M (1982) Late Cretaceous and early Miocene Andean type plutonic activity in northern Makran and central Iran. J Geol Soc Lond 139:605-614

Cameron EM, Hamilton SM, Leybourne MI, Hall GEM, McClenaghan B (2004) Finding deeply-buried deposits using geochemistry. Geochem Explor Environ Anal 4:7-32

Caron ME, Grasby SE, Cathryn Ryan M (2008) Spring water trace element geochemistry: a tool for resource assessment and reconnaissance mineral exploration. Appl Geochem 23:3561-3578

Dargahi S, Arvin M, Pany Babaei A (2010) Petrogenesis of postcollisional A-type granitoids from the Urumieh-Dokhtar magmatic assemblage, Southwestern Kerman, Iran: constraints on the Arabian-Eurasian continental collision. Lithos 115:190-204

Demdoum A, Hamed Y, Feki M, Hadji R, Djebbar M (2014) Multitracer investigation of groundwater in El Eulma Basin (northwestern Algeria), North Africa. Arab J Geosci. doi:10.1007/s 12517-014-1377-z

Giammanco S, Ottaviani M, Veschetti E (2007) Temporal Variability of major and trace element concentrations in the groundwaters of Mt. Etna (Italy): effects of transient input of magmatic fluids highlighted by means of cluster analysis. Pure Appl Geophys 164:2523-2547

Halim MA, Majumder RK, Nessa SA, Hiroshiro Y, Uddin MJ, Shimada J, Jinno K (2009) Hydrogeochemistry and arsenic contamination of groundwater in the Ganges Delta Plain, Bangladesh. J Hazard Mater 164:1335-1345

Hame Y, Ahmadi R, Demdoum A, Gargouri I, Hadji R, Bouri S, Ben Dhia H, Al Gamal S, Laouar R, Choura A (2014) Use of geochemical, isotopic, and age tracer data to develop models of groundwater flow: a case study of Gafsa mining basin-Southern Tunisia. J Afr Earth Sci 100:418-436. doi:10.1016/j.jafrearsci. 2014.07.012

Hartikainen A (1992) Regional multimedia geochemical exploration for $\mathrm{Au}$ in the Tokaj Mountains, northeast Hungary. Appl Geochem 7:533-545

Hubner H (1969) Geological map of Iran sheet no. 5, southcentral Iran. National Iranian Oil Company, scale 1:1,000,000, Tehran
Jeevanandam M, Kannan R, Srinivasalu S, Rammohan V (2007) Hydrogeochemistry and groundwater quality assessment of lower part of the Ponnaiyar River Basin, Cuddalore District, South India. Environ Monit Assess 132:263-274

Manjo K, Kumar B, Padhy PK (2012) Characterisation of metals in water and sediments of Subarnarekha River along the projects' sites in lower basin, India. Univ $\mathrm{J}$ Environ Res Technol 2(5):402-410

Miller WR, Ficklin WH, Learned RE (1982) Hydrogeochemical prospecting for porphyry copper deposits in the tropical-marine climate of Puerto Rico. J Geochem Explor 16:217-233

Pazand K (2014) Geochemical and hydrogeochemical evolution of groundwater in Ferdows area, northeast of Iran. Environ Earth Sci 71:685-695

Pazand K, Hezarkhani A, Ghanbari Y, Aghavali N (2012) Geochemical and quality assessment of groundwater of Marand Basin, East Azarbaijan Province, northwestern Iran. Environ Earth Sci 67:1131-1143

Paznand K, Javanshir AR (2013) Hydrogeochemistry and arsenic contamination of groundwater in the Rayen area, southeastern Iran. Environ Earth Sci 70:2633-2644

Paznand K, Javanshir AR (2014) Rare earth element geochemistry of spring water, north western Bam, NE Iran. Appl Water Sci $4: 1-9$

Petersen AT, Hansen HCB, Nybroe O (2004) Time and moisture effect on total and bioavailability copper in soilwater extracts. J Environ Qual 33:505-512

Plumlee GS, Smith KS, Montour MR, Ficklin WH, Mosier EL (1999) Geologic controls on the composition of natural waters and mine waters draining diverse mineral-deposit types. Rev Econ Geol (Chapter 19, vol 6A and 6B)

Raghunath HM (1987) Ground water. Willey, New York

Rasoli J, Ghorbani M (2011) Geochemical and mineralogical study of Koror (East of Jebal-e-Barez). Geology Conferences, Geology Survey of Iran, Tehran (in Farsi)

Regard V, Bellier O, Thomas JC, Abbassi MR, Mercier J, Shabanian E, Feghhi K, Soleymani S (2004) Accommodation of ArabiaEurasia convergence in the Zagros-Makran transfer zone, SE Iran: a transition between collision and subduction through a young deforming system. Tectonics 23(4):24

Shafiei B, Haschke M, Shahabpour J (2009) Recycling of orogenic arc crust triggers porphyry $\mathrm{Cu}$ mineralization in Kerman Cenozoic arc rocks, southeastern Iran. Miner Depos 44:265-283

Smedley PL, Edmunds WM (2002) Redox patterns and trace element behavior in the East Midlands Triassic Sandstone Aquifer, UK. Ground Water 40:44-58

Taufen PM (1997) Ground waters and surface waters in exploration geochemical surveys. Explor Geochem 271-284

Verplanck PL, Mueller SH, Goldfarb RJ, Nordstrom DK, Youcha EK (2008) Geochemical controls of elevated arsenic concentrations in groundwater, Ester Dome, Fairbanks district, Alaska. Chem Geol 255:160-172 